\title{
Underlying mechanisms involved in the decrease of milk secretion during Escherichia coli endotoxin induced mastitis in lactating mice
}

\author{
Ken Kobayashi", Shoko Oyama, Takaaki Uejyo, Chinatsu Kuki, Md Morshedur Rahman and Haruto Kumura
}

\begin{abstract}
Mastitis, the inflammation of mammary glands resulting from bacterial infection, disrupts milk production in lactating mammary glands. In this study, we injected lipopolysaccharide (LPS), one of the endotoxins from Escherichia coli into mouse mammary glands to disrupt milk production, and we investigated the influence of LPS on nutrient uptake, synthesis, and secretion processes for milk component production in alveolar epithelial cells (AEC). The expression of genes relevant to the three-staged milk component production process (nutrient uptake, synthesis, and secretion of milk components) were down-regulated within $12 \mathrm{~h}$ after LPS injection in AEC. The internalization of glucose transporter 1 (GLUT-1) from the basolateral membrane to the cytoplasm occurred in accordance with the down-regulation of gene expression $3 \mathrm{~h}$ after LPS injection. The abnormal localization of adipophilin and beta-casein was also observed in the LPS-injected mammary glands. SLC7A1, an amino acid transporter, was up-regulated 3 and $6 \mathrm{~h}$ after LPS injection. Furthermore, the inactivation of signal transducer and activator of transcription 5 (STAT5) and the activation of STAT3 and nuclear factor-kappa B (NFkappaB) occurred $3 \mathrm{~h}$ after LPS injection. These results indicate that the nutrient uptake, synthesis, and secretion of milk components in AEC are rapidly shut down in the lactating mammary glands after LPS injection.
\end{abstract}

\section{Introduction}

Mammary glands supply milk as the sole nutrient source for suckling pups and maintain galactopoiesis during lactation. The milk contains abundant nutritive components such as caseins, lactose, and lipids. Such milk components are produced by the mammary alveolar epithelial cells (AEC). AEC take up nutrients from the blood stream as raw materials and synthesize several milk components in the subcellular organelles. Synthesized components are directionally secreted into the alveolar lumen through the apical membrane of AEC. Thus, AEC carry out milk component production through a three-staged process: nutrient uptake, synthesis, and secretion of milk components during lactation. However, mastitis, the inflammation of mammary glands resulting from bacterial infection, disrupts normal milk secretion from AEC [1]. Milk is the indispensable nutrient source for suckling offspring in mammals, and

\footnotetext{
* Correspondence: kkobaya@anim.agr.hokudai.ac.jp

Laboratory of Dairy Food Science, Research Faculty of Agriculture, Hokkaido University, North 9, West 9, Sapporo 060-8589, Japan
}

mastitis is the most costly common disease in the dairy industry. Therefore, it is important to know how infected bacteria inhibit milk component production through a three-staged process in AEC in mastitis.

At the first stage of milk component production, AEC take up glucose, glycerol, fatty acids, and amino acids as raw materials for milk component synthesis from the blood capillary network, which closely surrounds mammary alveoli [2]. To take up the enormous amount of raw materials, several types of transporters and channels exist in the basolateral membranes of AEC. Aquaporin 3 (AQP3) is a water and glycerol channel and localizes in the basolateral membrane of secretory AEC [3]. Glucose transporter 1 (GLUT-1) also exists in the basolateral membrane of ACE in lactating mammary glands [4]. The fatty acid transporter (solute carrier family 27, SLC27A) enhances the uptake of long-chain fatty acids into cells [5,6]. Neutral amino acid transporter 1 (ASCT1) and cationic amino acid transporter (CAT)-1, which are proteins encoded by the SLC1A4 and SLC7A1 
genes, respectively, are expressed in porcine mammary glands during lactation [7].

At the second stage of milk component production, AEC synthesize milk components from raw materials. Milkspecific proteins such as caseins and whey acidic protein (WAP) are synthesized from amino acids stimulated by hormonal regulation via Signal Transducer and Activator of Transcription 5 (STAT5) activation during late pregnancy [8-11]. AEC also initiate the synthesis of lactose at the Golgi around the time of parturition [12]. Alphalactalbumin modifies the substrate specificity of UDPglucosyltransferase and leads to the synthesis of lactose from glucose and UDP-galactose [13]. Triglycerides, the major lipid component of milk, are synthesized from glucose, glycerol, and fatty acids in or on the surface of the rough endoplasmic reticulum and are released into the cytoplasm as small cytoplasmic lipid droplets (CLD) [14]. The sterol regulatory element binding protein 1 (SREBP1) is a critical regulator of mammary secretory activation with regard to lipid biosynthesis $[15,16]$. Fatty acid binding protein 3 (FABP3) has also been reported to contribute to lipid biosynthesis by facilitating the intracellular transport of fatty acids [17]. These reports suggest that proteins, lactose, and lipids require gene expression relevant to their synthesis pathway in addition to raw materials.

At the final stage of milk component production, milk components are transferred to the apical membrane of AEC and are released into the alveolar lumen through specific intracellular pathways [18]. Caseins and lactose are released by exocytosis from the Golgi as secretory vesicles. Soluble $\mathrm{N}$-ethylmaleimide-sensitive factor attachment protein receptor (SNARE) proteins regulate intracellular trafficking and exocytosis of secretory vesicles through the plasma membrane $[19,20]$. Specific SNARE proteins are predominantly arranged in distinct subcellular compartments and contribute to distinct trafficking pathways [21,22]. In lactating mammary glands, several SNARE proteins have been reported to be expressed in AEC, and SNAP-23, syntaxin-6, -7, and -12 , as well as VAMP- 4 and -8 have been suggested as candidate SNARE proteins involved in milk secretion in AEC [23]. Small CLD, which are synthesized in the rough endoplasmic reticulum, are released into the cytoplasm with a surface coat of proteins and polar lipids [24]. Small CLD fuse with each other and form larger CLD when being trafficked to the apical membrane [25]. Adipophilin has been identified as a major protein coating CLD and milk lipid globules (MLG), and the increase in the expression of adipophilin is correlated with the accumulation of CLD in AEC [15,26]. Adipophilin has also been suggested to function as an adaptor linking CLD to elements of the apical plasma membrane to facilitate their secretion with SNARE proteins $[24,25,27]$. Lipids exist in milk as MLG, which is a unique membrane-bound structure released in an apocrine fashion [28]. These reports suggest that some of the SNARE proteins and adipophilin are closely related with the exocytosis of secretory vesicles and the apocrine secretion of CLD.

AEC maintain nutrient uptake, synthesis, and secretion of milk components during lactation [29]. The normal milk production in lactating mammary glands is disrupted by mastitis, the inflammation of mammary glands resulting from bacterial infection [30,31]. However, it remains unclear how and when the three-staged milk component production process is inhibited in mastitis. In this study, we injected lipopolysaccharide (LPS), one of the endotoxins from Escherichia coli into mouse mammary glands to disrupt milk production because intramammary administration of LPS is a wellestablished method for experimental induction of mastitis under defined conditions to study the immune response of the mammary gland in cows [32-34]. AEC directly bind to LPS via the LPS-specific receptor, Tolllike receptor $4[31,35]$. We have previously reported that the rapid induction of apoptosis in AEC occurs immediately after LPS injection [36]. LPS weakens the milkblood barrier by modulating claudins in AEC within $3 \mathrm{~h}$ after LPS treatment [37]. Thus, LPS adversely affects lactating AEC shortly after injection. Therefore, we investigated how and when AEC shut down galactopoiesis after LPS injection.

\section{Materials and methods \\ Animals}

Pregnant ICR mice were purchased from Japan SLC, Inc. (Shizuoka, Japan). After parturition, the lactating mice were kept with the suckling neonatal pups. LPS originating from E. coli 0111:B4 was solubilized in $0.5 \mathrm{mM} \quad \mathrm{CaCl}_{2}$ and $0.5 \mathrm{mM} \quad \mathrm{MgCl}_{2}$-containing phosphate-buffered saline (mPBS). LPS $(20 \mu \mathrm{g})$ was injected into the fourth inguinal mammary gland via the teat canal without injury on day 10 of lactation under anesthesia with pentobarbital. Three, 6 , or $12 \mathrm{~h}$ after LPS injection, the mice were decapitated, and the mammary glands were dissected. In addition, mice were removed from pups $30 \mathrm{~min}$ before dissection. In each of the experiments, the dissected mammary glands were washed with $\mathrm{mPBS}$ and then used immediately. In this study, we used non-treated mammary glands from nontreated mice as the control ( $0 \mathrm{~h}$ of LPS injection) because vehicle (mPBS)-injected mammary glands did not show any differences from mammary glands of mice without injection treatment [36,37]. All experimental procedures in this study were approved by the Animal Resource Committee of Hokkaido University and were conducted in accordance with the Hokkaido University guidelines for the care and use of laboratory animals. 


\section{Materials}

LPS was purchased from Sigma-Aldrich (St. Louis, MO). The following antibodies were used as primary antibodies for immunological studies: rabbit polyclonal antibodies against AQP3 (Alpha Diagnostic, San Antonio, TX), GLUT-1 (Millipore, Billerica, MA, USA), nuclear factor-kappa B (NFkB, Cell Signaling Technology, Danvers, MA, USA), phosphorylated-NFkB (Ser536, Cell Signaling), STAT3 (Santa Cruz Biotechnology, Santa Cruz, CA, USA), phosphorylated-STAT3 (pSTAT3, Tyr705, Cell Signaling), STAT5 (Cell Signaling), phosphorylated-STAT5 (pSTAT5, Tyr694, Cell Signaling), mouse monoclonal antibody against pan-keratin (Sigma-Aldrich), rat monoclonal antibody against CD11b (BioLegend, San Diego, CA, USA), goat polyclonal antibody against $\beta$-casein (Santa Cruz), and guinea pig polyclonal antibody against adipophilin (Cell Signaling). Secondary Alexa Fluor 488-conjugated goat anti-rabbit, anti-guinea pig, Alexa Fluor 546conjugated goat anti-mouse, anti-rat, and Alexa Fluor 546-conjugated donkey anti-goat antibodies were purchased from Invitrogen/Molecular Probes (Eugene, OR, USA). The secondary horseradish peroxidase-conjugated anti-mouse, anti-rabbit, and anti-goat antibodies for western blotting analysis were purchased from Sigma-Aldrich.

\section{Quantitative real-time polymerase chain reaction}

For quantitative real-time polymerase chain reaction (PCR), total RNA from the mammary glands was extracted using an RNeasy ${ }^{\odot}$ Mini Kit (Qiagen, Valencia, CA, USA) according to the manufacturer's instructions. Reverse transcription was performed using ReverTraAce $^{\curvearrowleft}$ qPCR RT Master Mix (Toyobo, Osaka, Japan). Quantitative real-time PCR was performed in a Light Cycler $^{\oplus} 480$ (Roche Applied Science, Indianapolis, IN, USA) using the THUNDERBIRD ${ }^{\circ}$ SYBR $^{\oplus}$ qPCR Mix (Toyobo). The following outlines the amplification program: $95{ }^{\circ} \mathrm{C}$ for $1 \mathrm{~min}$ followed by 40 cycles at $95{ }^{\circ} \mathrm{C}$ for $15 \mathrm{~s}$ and $58{ }^{\circ} \mathrm{C}$ for $1 \mathrm{~min}$. The information about primers is listed in Table 1. Glyceraldehyde-3-phosphate dehydrogenase (GAPDH) was used as an internal control.

\section{Immunofluorescence staining}

For immunofluorescence staining of paraffin sections (AQP3, pan-keratin, $\beta$-casein, adipophilin, and pSTAT3), the mammary glands were fixed with $4 \%$ formaldehyde in PBS, pH 7.4, for 1 day at $4{ }^{\circ} \mathrm{C}$ and embedded in paraffin. The embedded samples were sliced into 5- $\mu \mathrm{m}$ sections, and the sections were deparaffinized and hydrated. The sections were then immersed in antigen retrieval buffer (10 mM Tris and 0.5 mM EGTA in distilled water,

Table 1 Primer sequences for real-time PCR in mouse mammary glands.

\begin{tabular}{|c|c|c|c|c|}
\hline Gene & $\begin{array}{l}\text { Accession } \\
\text { number }\end{array}$ & $\begin{array}{l}\text { Primers } \\
\text { Forward }\end{array}$ & Reverse & Product size \\
\hline SLC1A4 & NM_018861 & cgcaggacagattttcacca & catccccttccacattcacc & 197 \\
\hline SLC7A1 & NM_007513 & cgtccctcctcatttgcttc & gcgattacgggtgttttggt & 289 \\
\hline SLC27A3 & NM_011988 & tctgggacgattgccagaaac & caagcgcaccttatggtcacac & 116 \\
\hline AQP3 & NM_016689 & ctggacgctttcactgtgggc & gatctgctccttgtgtttcatg & 309 \\
\hline GLUT-1 & NM_011400 & gcttcctgctcatcaatcgt & gccgaccctcttctttcatc & 117 \\
\hline UGP2 & NM_139297 & tcacaaacaaaacacgagcaga & cacttgagcgatttccacca & 89 \\
\hline PGM2 & NM_028132 & caagcaagctgtccctctgt & gatgtcctccacgctctgtt & 137 \\
\hline a-lactalbumin & NM_010679 & accagtggctacgacacac & cggggaactcactacttttacac & 106 \\
\hline FABP3 & NM_010174 & agtcactggtgacgctggacg & aggcagcatggtgctgagctg & 230 \\
\hline SREBP-1 & NM_011480 & gtcagcttgtggcagtggag & tctgagggtggaggggtaag & 90 \\
\hline CSN1S1 & NM_007784 & cctttcccctttgggettac & tgaggtggatggagaatgga & 193 \\
\hline CSN2 & NM_009972 & cttcagaaggtgaatctcatggg & cagattagcaagactggcaagg & 330 \\
\hline CSN3 & NM_007786 & tcgaccccattactcccattgtgt & tgtaaaaggtaagggaagacgagaaagat & 289 \\
\hline WAP & NM_011709 & aacattggtgttccgaaagc & agggttatcactggcactgg & 179 \\
\hline Lactoferrin & NM_008522 & ggctgagaaggcaggaaatg & tttggggctatggctaggtg & 183 \\
\hline VAMP-3 & NM_009498 & gctgccactggcagtaatcgaagac & gagagcttctggtctctttc & 113 \\
\hline VAMP-4 & NM_016796 & gggaccatctggaccaagatttgg & catccacgccaccacatttgcctt & 225 \\
\hline Syntaxin-6 & NM_021433 & cgactggacaacgtgatgaa & ctgggcgaggaatgtaagtg & 216 \\
\hline SNAP-23 & NM_001177792 & gtgttgtggcctctgcatct & ccatctcatcttctctggcatc & 254 \\
\hline Adipophilin & NM_007408 & caggggtggtggataagacc & ggtgataagcccgagagca & 291 \\
\hline GAPDH & NM_008084 & gagcgagaccccactaacatc & gcggagatgatgaccctttt & 144 \\
\hline
\end{tabular}


$\mathrm{pH}$ 9.0) and heated in a microwave oven at $500 \mathrm{~W}$ for $20 \mathrm{~min}$.

For immunofluorescence staining of frozen sections (GLUT-1, pan-keratin, CD11b, and NFkB), mammary glands were embedded in OCT compound (Tissue Tek, Sakura, Torrance, CA, USA) and rapidly frozen with liquid nitrogen. The frozen samples were sliced into $5-\mu \mathrm{m}$ sections with a Leica CM 3050S cryomicrotome (Mannheim, Germany). The sections were fixed with $1 \%$ formaldehyde in PBS for $10 \mathrm{~min}$ at $4{ }^{\circ} \mathrm{C}$ and then with methanol for $10 \mathrm{~min}$ at $-20{ }^{\circ} \mathrm{C}$.

The paraffin-embedded and frozen sections were incubated with PBS containing 5\% bovine serum albumin to block nonspecific interactions and were then treated with the respective primary antibody (diluted in blocking solution) overnight at $4{ }^{\circ} \mathrm{C}$. After the sections were washed with PBS, they were exposed to the secondary antibody for $1 \mathrm{~h}$ at room temperature in blocking solution. Controls were treated in the same manner, except for the exclusion of the primary antibody. Images of the stained sections were obtained using a confocal laserscanning microscope (TCS SP5; Leica) and LAS AF software (Leica).

\section{Western blotting analysis}

The mammary glands were minced and lysed in buffer containing $1 \%$ Triton X-100, 1\% SDS, $100 \mathrm{mM}$ $\mathrm{NaCl}, 10$ mM HEPES (pH 7.4), 2 mM EDTA, a phosphatase inhibitor mixture (PhosStop, Roche), and a protease inhibitor mixture (complete mini, Roche). The lysates were then diluted with an equal volume of sample buffer (100 mMTris (pH 6.8), $100 \mathrm{mM}$ dithiothreitol, $2 \%$ SDS, $0.2 \%$ bromophenol blue, and 20\% glycerol), incubated for $10 \mathrm{~min}$ at $70{ }^{\circ} \mathrm{C}$, and stored at $-20{ }^{\circ} \mathrm{C}$ as samples for Western blotting.

The samples were electrophoresed using $8 \%$ or $12 \%$ sodium dodecyl sulfate-polyacrylamide gels and transferred onto polyvinylidene difluoride membranes (BioRad, Hercules, CA, USA). The membranes were blocked for $1 \mathrm{~h}$ with PBS containing 4\% nonfat dried milk and $0.05 \%$ Tween 20 . In the case of $\beta$-casein, PBS containing $2 \%$ bovine serum albumin was used for blocking. The membranes were incubated overnight at $4{ }^{\circ} \mathrm{C}$ with primary antibodies diluted in PBS containing $2.5 \%$ bovine serum albumin. Subsequently, the membranes were washed in PBS containing $0.05 \%$ Tween 20 and incubated for $45 \mathrm{~min}$ at room temperature with the appropriate secondary horseradish peroxidase-conjugated antibodies diluted in the solutions used for blocking. The immunoreactive bands were detected using Luminate Forte Western HRP substrate (Millipore). The protein bands were visualized and quantified using a Bio-Rad ChemiDoc ${ }^{\mathrm{TM}}$ EQ densitometer.

\section{Measurement of lactose, triglycerides, and $\beta$-casein}

Lactose, triglycerides, and $\beta$-casein, which were secreted and accumulated in mammary alveolar lumens and ducts as milk components, were extracted from the mammary glands of mice non-treated or treated with LPS. The minced mammary glands were suspended in 9 times its weight of PBS and then passed 30 times through a 19-gauge needle. The suspension was then centrifuged at $1500 \times g$ for $5 \mathrm{~min}$ at room temperature. The supernatant (extract of accumulated milk in mammary alveolar lumens and ducts) was used for the measurement of lactose, triglycerides, and $\beta$-casein.

The measurement of lactose was performed using the F-kit for lactose/galactose (Boehringer Mannheim GmbH, Mannheim, Germany). Briefly, each extract was warmed at $70{ }^{\circ} \mathrm{C}$ for $15 \mathrm{~min}$ and mixed with 2 types of reaction buffers according to the manufacturer's protocol. After incubation for $15 \mathrm{~min}$ at $25{ }^{\circ} \mathrm{C}$, the absorbance of each mixture was measured at $340 \mathrm{~nm}$.

The measurement of triglycerides was performed using the Adipogenesis Assay Kit (Biovision Inc., Mountain View, CA, USA) according to the manufacturer's protocol. Briefly, each extract was warmed at $70{ }^{\circ} \mathrm{C}$ for $15 \mathrm{~min}$ and then diluted 9-fold with Lipid Extraction Solution. The diluted supernatant $(50 \mu \mathrm{L})$ was transferred to each well of a 96-well assay plate followed by the addition of $50 \mu \mathrm{L}$ of Assay Buffer and $2 \mu \mathrm{L}$ of lipase solution to each well. After incubation for $10 \mathrm{~min}$ at $25^{\circ} \mathrm{C}, 50 \mu \mathrm{L}$ of the triglyceride reaction mixture was added to each well. The plate was incubated at $37^{\circ} \mathrm{C}$ for $30 \mathrm{~min}$, and the absorbance was read at $570 \mathrm{~nm}$.

Beta-casein in the extract was measured by densitometry analysis of the $\beta$-casein bands detected by Western blotting. Each extract was vigorously vortexed and then diluted with $5 \times$ Laemmli sample buffer for electrophoresis. After western blotting, densitometry analysis of the $\beta$-casein bands was performed using a Bio-Rad ChemiDoc $^{\mathrm{TM}} \mathrm{EQ}$ densitometer.

\section{Statistical analysis}

Data are expressed as the mean (SD). The statistical significance of differences between the mean values was tested using a Student's $t$ test. Differences between the mammary glands of mice non-treated or treated with LPS were considered significant at a $p$-value $<0.05$ and 0.005. All experiments were performed at least 4 times using different mice to ensure reproducibility.

\section{Results}

\section{LPS down-regulates genes relevant for nutrient uptake}

To evaluate the influences of LPS on the nutrient uptake process, we examined the expression levels of amino acid transporters (SLC1A4, SLC7A1), a fatty acid transporter (SLC27A3), a water and glycerol channel (AQP3), 
and a glucose transporter (GLUT-1) by real-time PCR. The expression level of SLC1A4 decreased by half at $3 \mathrm{~h}$ after LPS injection and was less than one-fifteenth of that observed in non-treated mammary glands after $12 \mathrm{~h}$ (Figure 1A). In contrast to SLC1A4, SLC7A1 showed a 4-fold increase in the expression level at $6 \mathrm{~h}$ after LPS injection and then returned to the expression level of non-treated mammary glands after $12 \mathrm{~h}$ (Figure 1B). The expression of SLC27A3 significantly declined by half at $3 \mathrm{~h}$ after LPS injection and was less than oneseventeenth of that seen in treated mammary glands at $12 \mathrm{~h}$ after LPS injection (Figure 1C). The expression level of AQP3 rapidly decreased after LPS injection to less than one-sixteenth of that observed in non-treated mammary glands and remained at the low expression level at 6 and $12 \mathrm{~h}$ after LPS injection (Figure 1D). The expression level of GLUT-1 significantly decreased approximately one-half at $3 \mathrm{~h}$ after LPS injection (Figure 1E).

The localization patterns of AQP3 and GLUT-1 were examined by immunostaining. The localization of AQP3 was observed clearly in the basolateral membrane of AEC (Figure 2A). The staining intensity of AQP3 became weak after LPS injection after $3 \mathrm{~h}$. GLUT-1 was localized in the basolateral membrane of AEC before LPS injection (Figure 2B). Three hours after LPS injection, the localization of GLUT-1 in the basolateral membrane was barely observed and GLUT-1 was sparsely localized to the basal sides of the cytoplasm. Six hours after LPS injection, GLUT-1 was localized across the cytoplasm but not on the plasma membrane. The localization of GLUT-1 partially returned to the basolateral membranes without obvious localization in the cytoplasm at $12 \mathrm{~h}$ after LPS injection.

\section{LPS down-regulates the genes relevant to the synthesis process}

The expression levels of genes related to the synthesis of milk components were determined by real-time PCR.
UDP-glucose pyrophosphorylase 2 (UGP2), phosphoglucomutase 2 (PGM2), and $\alpha$-lactalbumin participate in lactose synthesis [38]. The expression of UGP2 was gradually down-regulated and became less than one-fourth of the non-treated mammary glands at $12 \mathrm{~h}$ after LPS injection (Figure 3A). The expression level of PGM2 decreased by half at $3 \mathrm{~h}$ after LPS injection and was somewhat restored at $12 \mathrm{~h}$ after LPS injection (Figure 3B). The expression of $\alpha$-lactalbumin was steadily down-regulated and became less than one-two hundredths of the non-treated mammary glands $12 \mathrm{~h}$ after LPS injection (Figure 3C). FABP3 and SREBP-1 are involved in the synthesis of triglycerides. FABP3 significantly decreased at $6 \mathrm{~h}$ after LPS injection, and the expression level of FABP3 at $12 \mathrm{~h}$ after LPS injection was less than one-thirtieth of that observed in nontreated mammary glands (Figure 3D). The level of SREBP-1 decreased significantly at $3 \mathrm{~h}$ after LPS injection and remained at a low expression level at 6 and $12 \mathrm{~h}$ after LPS injection (Figure 3E). The gene expressions of milk-specific proteins were also quantified. CSNS1, CSN2, and CSN3 decreased significantly at $6 \mathrm{~h}$ after LPS injection (Figure 3F-H). Twelve hours after LPS injection, the expression levels of CSNS1, CSN2, and CSN3 were approximately one-third, one-seventeenth, and one-fourth of those observed in non-treated mammary glands, respectively. WAP expression significantly declined at $6 \mathrm{~h}$ after LPS injection and was approximately two-thirds of that seen in the nontreated mammary glands (Figure 3I). Lactoferrin increased significanly after LPS injection to nearly twice that of nontreated mammary glands (Figure 3J).

\section{LPS partially down-regulates the expression of genes rele- vant to milk component trafficking}

To evaluate the influence of LPS on the release of synthesized milk components, the expression levels of SNARE, which take part in cellular membrane trafficking of transport vesicles, were quantified by real-time PCR. The expression level of VAMP-3 significantly decreased at $3 \mathrm{~h}$ after

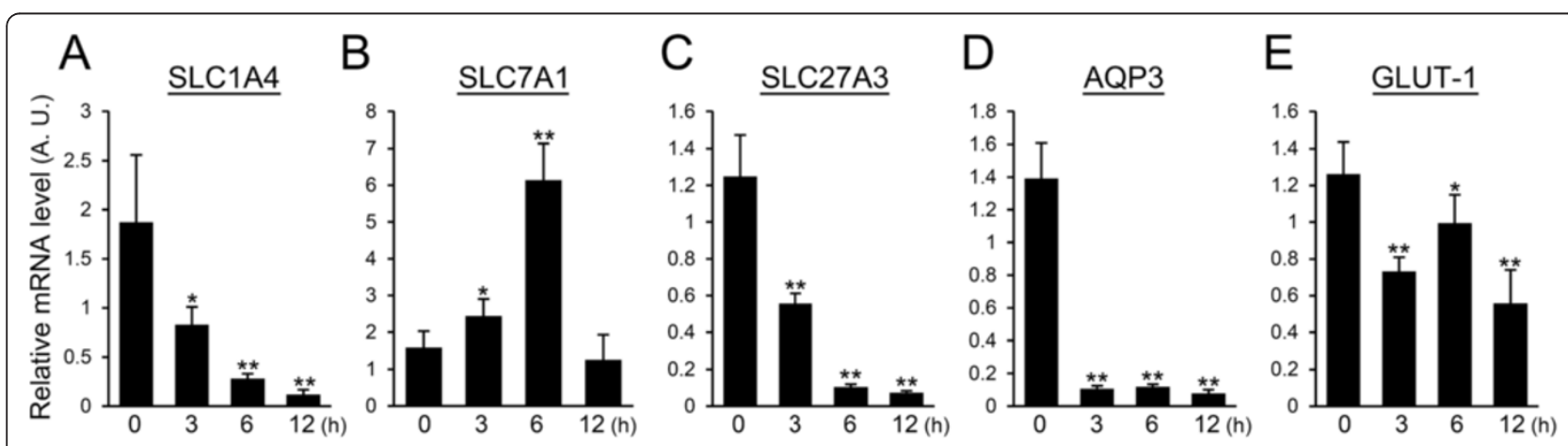

Figure 1 Influence of LPS on the gene expression of transport proteins and channel proteins required to supply raw materials for milk. Expression levels of SLC1A4 (A), SLC7A1 (B), SLC27A3 (C), AQP3 (D), and GLUT-1 (E) in mammary glands non-treated (0 h) and at 3, 6, and $12 \mathrm{~h}$ after LPS injection were quantified by real-time PCR. Data represent the mean (SD) $(n=6)$. ${ }^{*}, p<0.05 ;{ }^{*}, p<0.005$ vs. 0 h. 


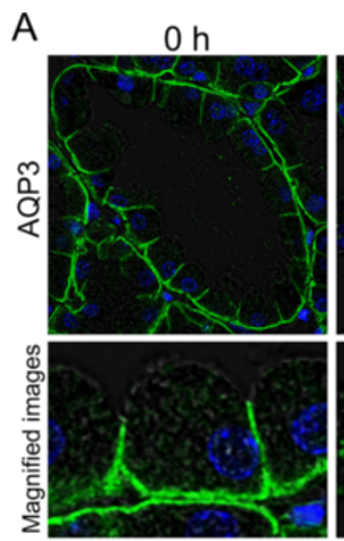

B
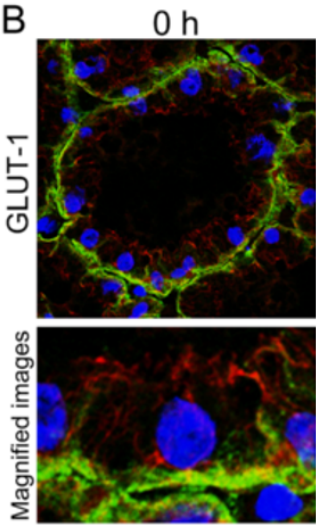

$3 \mathrm{~h}$

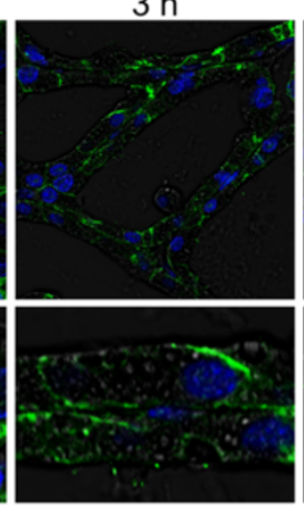

$3 \mathrm{~h}$

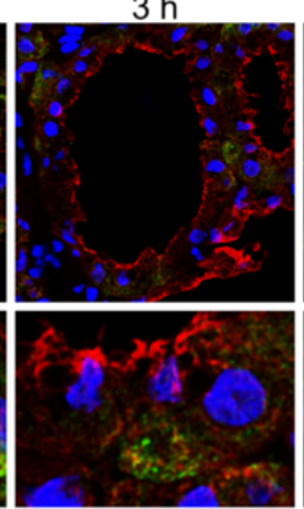

$6 \mathrm{~h}$

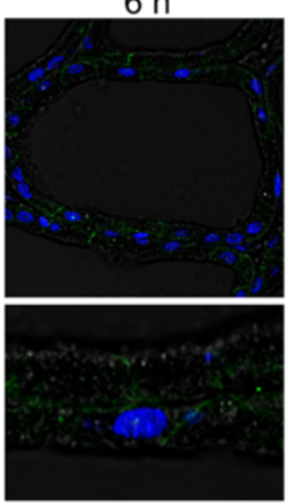

$6 \mathrm{~h}$

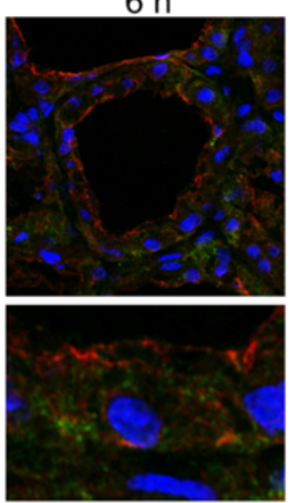

$12 \mathrm{~h}$

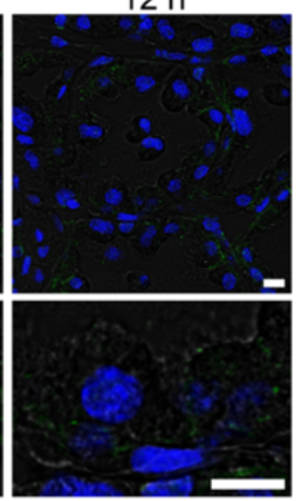

$12 \mathrm{~h}$

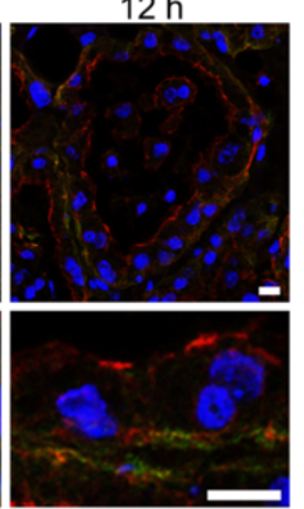

Figure 2 LPS influence on the localization of AQP3 and GLUT-1 in AEC. Mammary glands non-treated (0 h) and at 3, 6, and 12 h after LPS injection were immunostained with anti-AQP3 and anti-GLUT-1 antibodies. (A) Immunostained images of AQP3 (green) were merged with bright field images. (B) Immunostained images of GLUT-1 (green) were merged with pan-keratin (red) as a marker of epithelial cells. Blue represents nuclei stained with DAPI. Scale bars: $20 \mu \mathrm{m}$.

LPS injection but did not show a significant difference at 6 and $12 \mathrm{~h}$ after LPS injection (Figure 4A). VAMP-4 did not show a significant difference at 3 and $6 \mathrm{~h}$ after LPS injection but decreased to nearly one-third of that observed in nontreated mammary glands at $12 \mathrm{~h}$ after LPS injection (Figure 4B). The expression of syntaxin-6 in mammary glands treated with LPS increased approximately 2-fold compared to that of non-treated controls (Figure 4C). The expression level of SNAP-23 significantly decreased in mammary glands at 3 and $6 \mathrm{~h}$ after LPS injection and decreased to approximately one-third of that seen in nontreated mammary glands at $12 \mathrm{~h}$ after LPS injection (Figure 4D). We also investigated the expression level of adipophilin, which is involved in triglyceride storage and release. The adipophilin expression level declined after LPS injection similar to SNAP-23 (Figure 4E).

\section{LPS causes abnormal localization of milk components in AEC}

The localizations of $\beta$-casein and adipophilin were investigated to determine the influence of LPS on intracellular trafficking of milk-specific proteins and CLD, respectively.
Beta-casein was localized around the nuclei on the luminal side of the cytoplasm before LPS treatment (Figure 5A). At $3 \mathrm{~h}$ after LPS injection, $\beta$-casein was observed near the apical membrane. The staining intensity of $\beta$-casein became weak at $6 \mathrm{~h}$ after LPS injection. At $12 \mathrm{~h}$ after LPS injection, the staining intensity of $\beta$-casein was weak, and $\beta$-caseinnegative AEC were also observed.

Adipophilin is a CLD-binding protein that covers the surface of CLD. Several sizes of CLD covered by adipophilin were observed in the cytoplasm of AEC in non-treated mammary glands (Figure 5B). The adipophilin-positive CLD became large toward the apical membrane of AEC. At $3 \mathrm{~h}$ after LPS injection, large adipophilin-positive CLD decreased throughout the cytoplasm of AEC. Adipophilinpositive CLD were hardly observed at $6 \mathrm{~h}$ after LPS injection. Large CLD reappeared at $12 \mathrm{~h}$ after LPS injection.

\section{LPS causes the decrease in milk components in mammary glands}

To evaluate the influence of LPS on the release of major milk components, milk accumulated in the alveolar lumens and ducts was extracted from minced mammary 


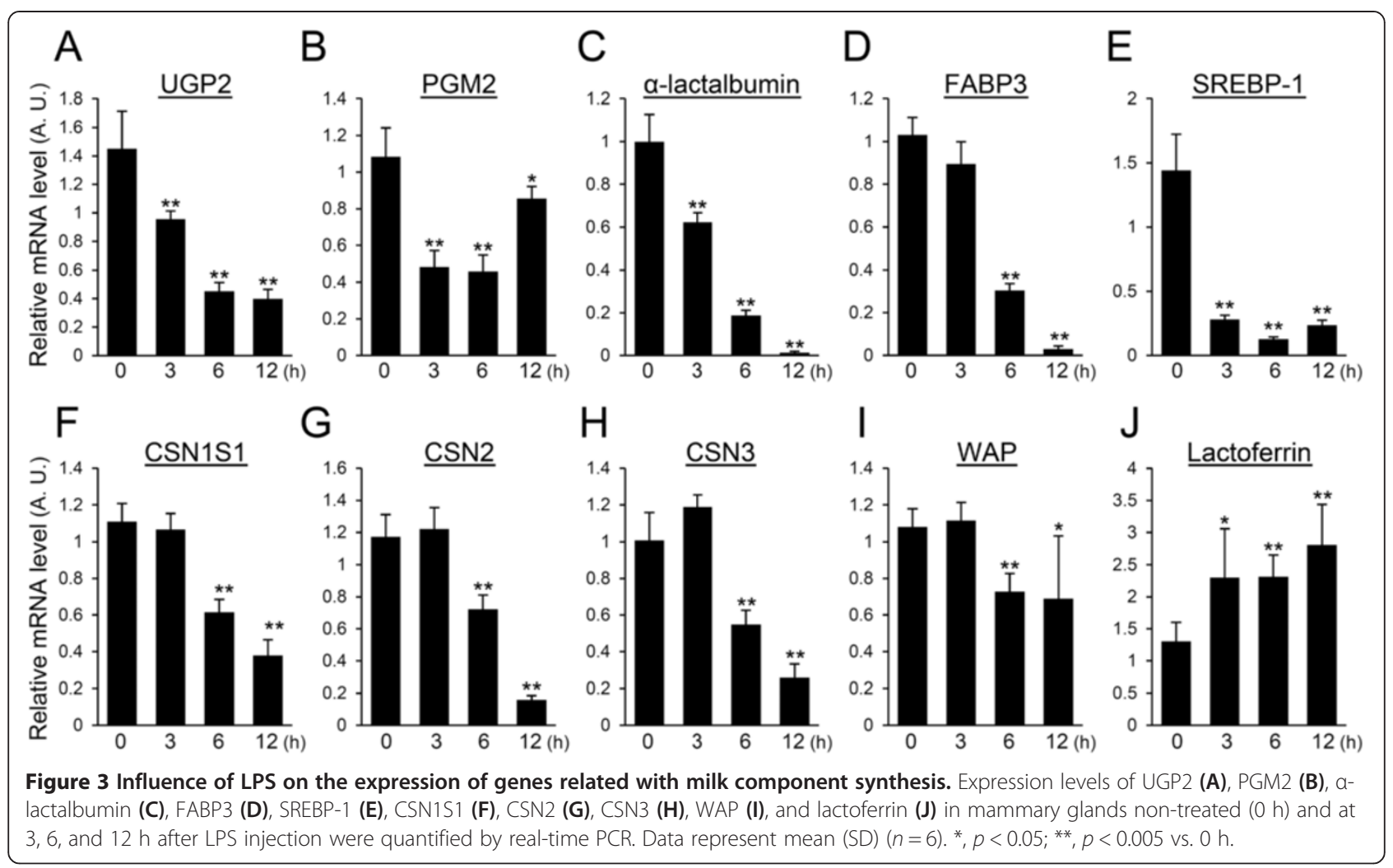

glands and used for the determination of triglycerides, lactose, and $\beta$-casein contents. After 3 and $6 \mathrm{~h}$, the concentration of triglycerides was approximately $6 \mathrm{mM}$ in the extracts from LPS-treated and non-treated mammary glands (Figure 6A). A significant decrease in the triglyceride concentration was observed at $12 \mathrm{~h}$ after LPS injection; the concentration was reduced to less than $2 \mathrm{mM}$. The concentration of lactose was also decreased at $12 \mathrm{~h}$ after LPS injection, and the concentration was less than one-twelfth of that observed in nontreated mammary glands (Figure 6B). The protein level of $\beta$-casein in the extracts increased at 3 and $6 \mathrm{~h}$ after
LPS injection and then decreased by half at $12 \mathrm{~h}$ after LPS injection compared to that of non-treated mammary glands (Figure 6C, D).

\section{LPS activates STAT3 and NFKB but inactivates STAT5}

The STAT3 and NFKB pathways are activated by phosphorylation, and STAT5 is inactivated by dephosphorylation after weaning, which simultaneously causes the loss of milk production ability in AEC [39,40]. To confirm which signaling pathways are activated or deactivated by LPS treatment, the phosphorylation of STAT3, STAT5, and NFкB was examined. Phosphorylated STAT5 was

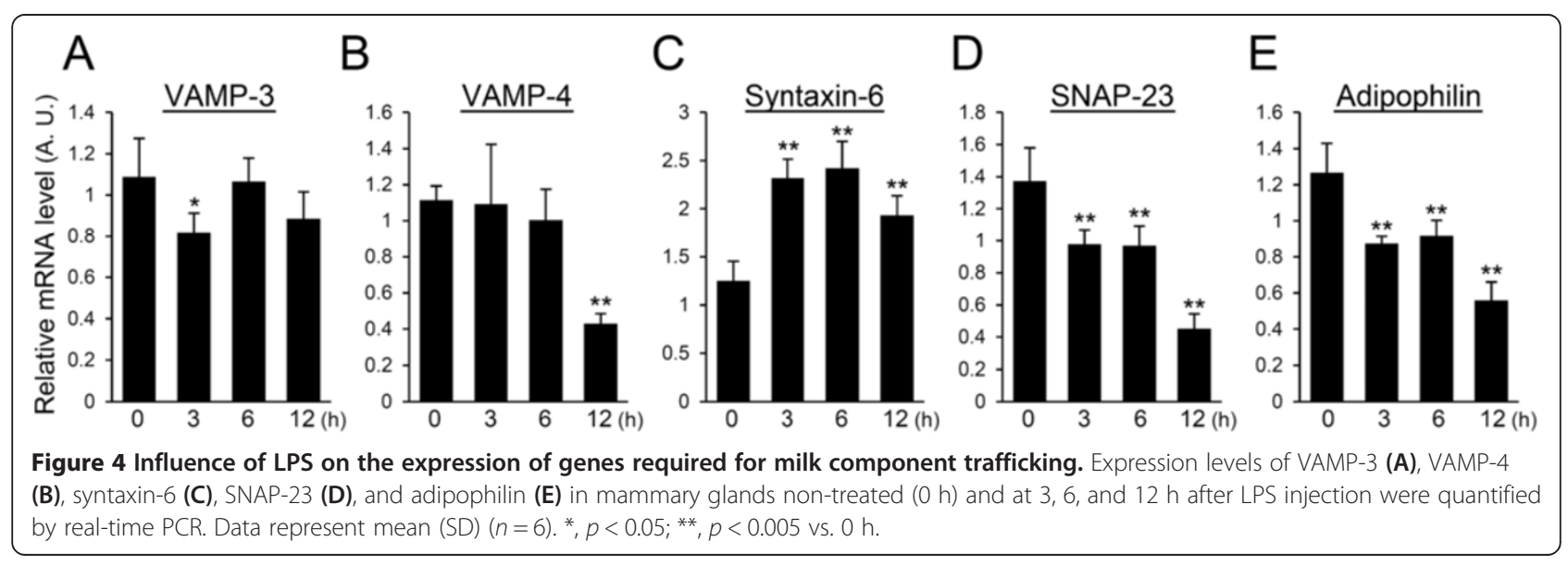



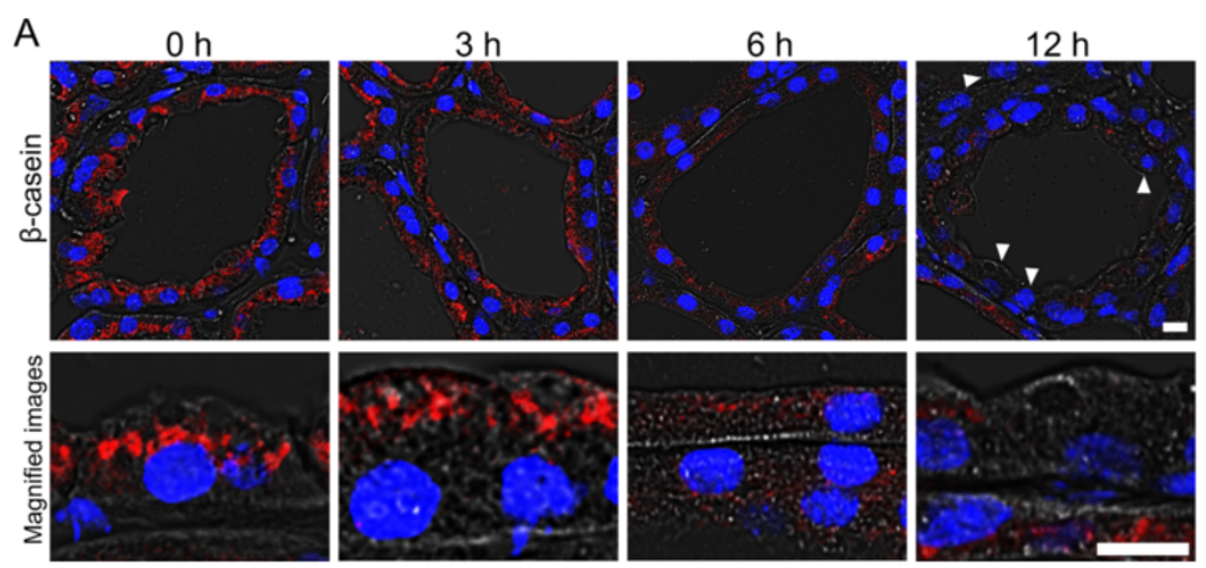

B

$\mathrm{Oh}$

\begin{abstract}
$3 \mathrm{~h}$
\end{abstract}
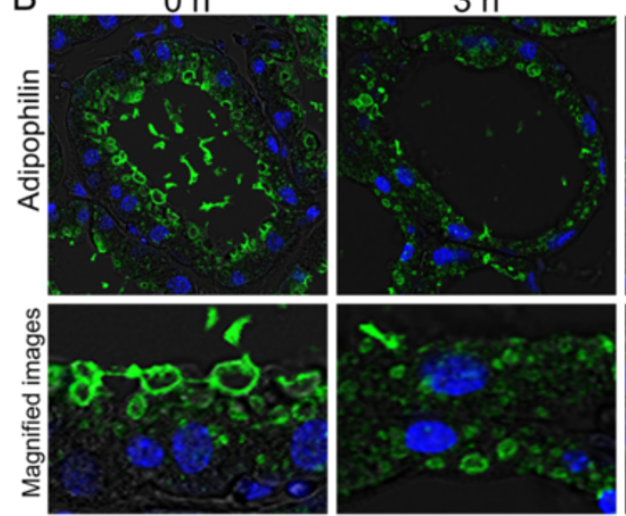

$6 \mathrm{~h}$

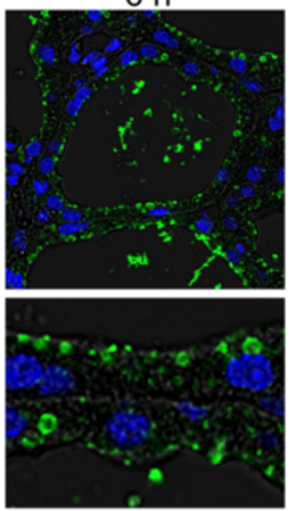

$12 \mathrm{~h}$

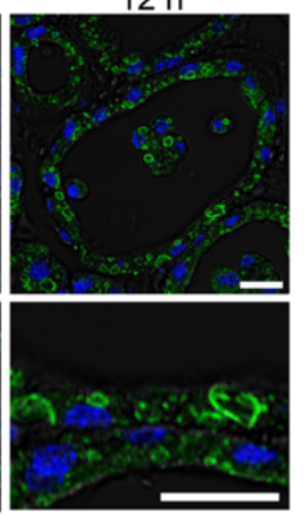

Figure 5 Influence of LPS on the localization of $\beta$-casein and adipophilin in AEC. Mammary glands non-treated ( 0 h) and at 3,6 , and $12 \mathrm{~h}$ after LPS injection were immunostained with anti- $\beta$-casein (red) and anti-adipophilin (green) antibodies. Immunostained images of $\beta$-casein (A) and adipophilin (B) were merged with bright field images and DAPI stained images (blue). Beta-casein-negative AEC were observed $12 \mathrm{~h}$ after LPS injection (arrowhead). Adipophilin staining shows the shape of lipid droplets in AEC. Scale bars: 20 um.

detected in non-treated mammary glands but was not observed in mammary glands at 3,6 , and $12 \mathrm{~h}$ after LPS injection (Figure 7). In contrast, phosphorylated STAT3 was detected at 3 and $6 \mathrm{~h}$ after LPS injection and its level was decreased at $12 \mathrm{~h}$ after LPS injection. Phosphorylated $\mathrm{NF}_{\kappa} \mathrm{B}$ was detected scarcely in non-treated mammary glands. An increase in phosphorylated NFKB was observed at $3 \mathrm{~h}$ after LPS injection. At $12 \mathrm{~h}$ after LPS injection, the levels of both NFkB and phosphorylated $\mathrm{NF} \mathrm{KB}$ decreased.

The activation of STAT3 and NFKB in AEC was detected by immunostaining. Phosphorylated STAT3 was localized in the nuclei of AEC at $3 \mathrm{~h}$ after LPS injection, although non-treated mammary glands did not show any positive reaction to phosphorylated STAT3 (Figure 8A). Phosphorylated STAT3 in the nuclei of AEC was also observed at $6 \mathrm{~h}$ after LPS injection, and some AEC showed phosphorylated STAT3 at $12 \mathrm{~h}$ after LPS injection. NFKB is known to be activated by phosphorylation in accordance with its translocation from the cytoplasm to the nucleus. The immunostaining of $\mathrm{NFKB}$ showed the translocation of $\mathrm{NFkB}$ from the cytoplasm to the nucleus in a portion of $\mathrm{AEC}$ at 3 and
$6 \mathrm{~h}$ after LPS injection, whereas NFkB was observed in the cytoplasm but not in the nucleus at $12 \mathrm{~h}$ after LPS injection (Figure 8B). In addition, an immunoreaction to CD11b, which is a marker of leukocytes containing neutrophils, was observed in some cells localized in the alveolar lumen and interstitial tissues [41].

\section{Discussion}

AEC express several lactation-specific genes to maintain milk component production during lactation [29]. However, it remains poorly understood how and when the milk component production shuts down after infection in mastitis. In this study, we categorized lactationspecific genes into the following 3 groups and investigated their temporal expression changes: nutrient uptake, synthesis, and secretion of milk components in AEC. The gene expressions of channels and transporters for the intake of water, glucose, glycerol, fatty acids, and amino acids were rapidly reduced by approximately half at $3 \mathrm{~h}$ after LPS injection. The immunostained images also revealed the decreases of GLUT-1 and AQP3 from the basolateral membranes of AEC at $3 \mathrm{~h}$ after LPS 


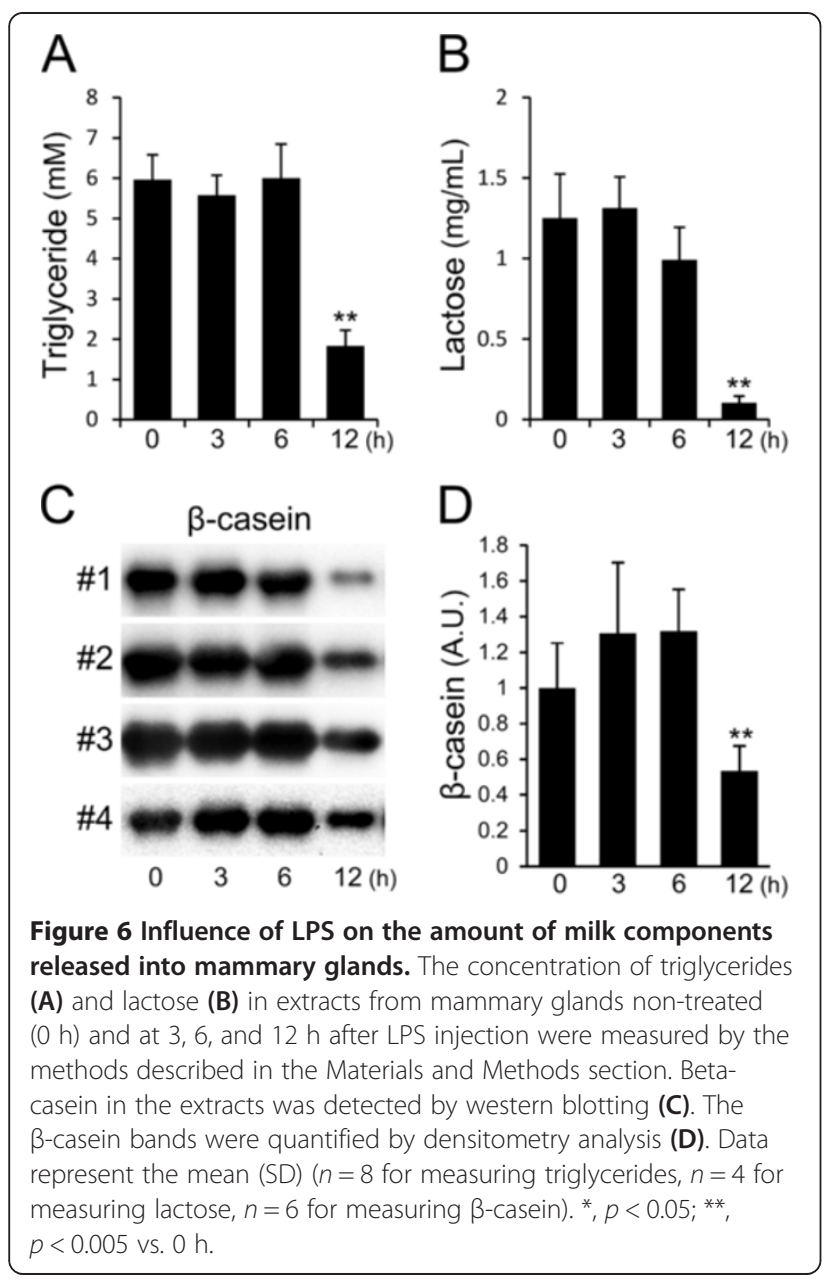

injection. These results indicate that the shutdown of the nutrient uptake occurs shortly after LPS injection. The expression levels of genes relevant to the synthesis of lactose and triglycerides declined by approximately half $3 \mathrm{~h}$ after LPS injection. The levels of 3 types of caseins and WAP also began to decrease at $6 \mathrm{~h}$ after LPS injection. The synthesis of milk components in AEC is also down-regulated within $6 \mathrm{~h}$ after LPS injection. Furthermore, the gene expressions for the secretion pathway and the exocytosis of milk components such as VAMP-4, SNAP-23, and adipophilin declined by approximately one-half were observed within $12 \mathrm{~h}$ after LPS treatment. Thus, LPS rapidly shut down the milk component production process, i.e., nutrient uptake, synthesis, and secretion of milk components in AEC.

Although the genes relevant to milk production are down-regulated in mastitis, lactoferrin and inflammatory cytokines such as interleukin (IL)-1ß, IL-6, and tumor necrosis factor- $\alpha$ are up-regulated [42]. LPS also induces the rapid increase in mRNA for IL-1 $\beta$, IL-8, and tumor necrosis factor- $\alpha$ after only $2 \mathrm{~h}$ in cultured bovine mammary epithelial cells [43]. In this study, lactoferrin was

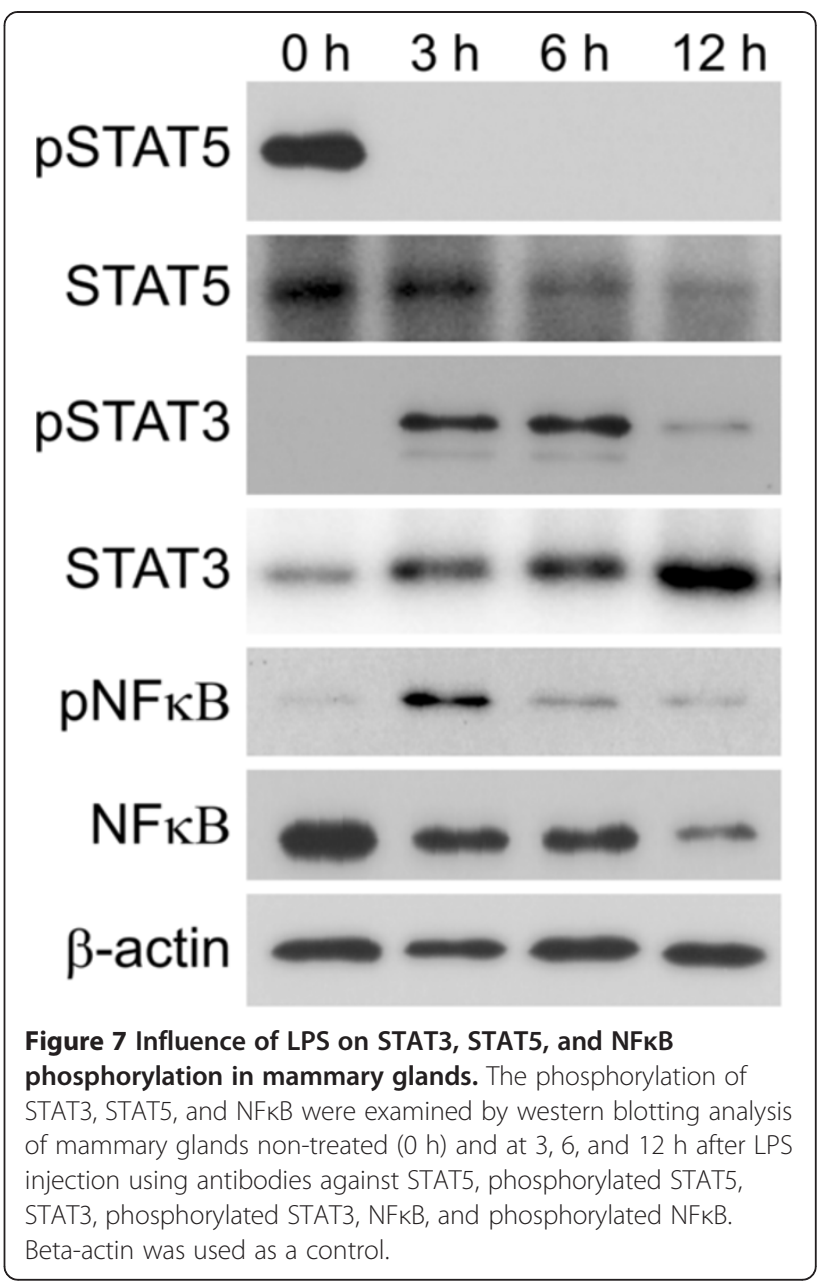

up-regulated after LPS injection although other genes relevant to the synthesis of milk components did not show up-regulation. Lactoferrin, which is released in infected tissues, is suggested to concern inflammation and immunomodulation processes in addition to its direct antimicrobial properties [44]. Thus, the up-regulation of inflammation-related proteins occurs simultaneously with the down-regulation of milk-specific proteins. In this study, SLC7A1, an amino acid transporter, and syntaxin-6, a SNARE protein, were upregulated. Interestingly, although the expression level of SLC1 A4 is not changed, the mRNA level of SLC7A1 increases in mammary glands at peak lactation compared to early lactation, suggesting the presence of different regulatory mechanisms between the expression of SLC1A4 and SLC7A1 [45]. Furthermore, in mammary glands, there are several SNARE proteins whose relationship with lactation or cellular secretion of milk components remains unclear [23]. SLC7A1 and syntaxin- 6 may contribute to the intake of amino acids and trafficking of inflammation-related proteins, respectively. 

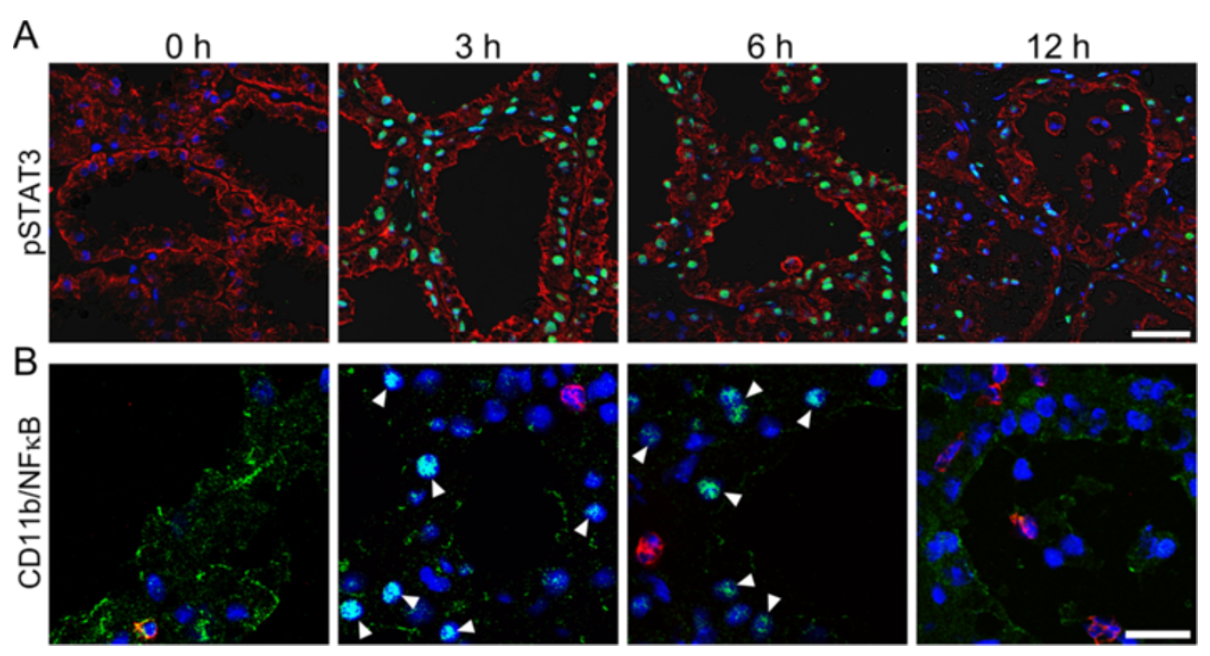

Figure 8 LPS causes phosphorylation of STAT3, translocation of NFKB, and invasion of CD11 $\mathrm{b}^{+}$leucocytes into the mammary alveolar lumen. Mammary glands non-treated (0 h) and at 3, 6, and $12 \mathrm{~h}$ after LPS injection were immunostained with anti-phosphorylated STAT3, antipan-keratin, anti-NFKB, and anti-CD11b antibodies. (A) Immunostained images of phosphorylated STAT3 (green) were merged with images of pan-keratin (red) as a marker of epithelial cells. (B) Immunostained images of NFKB (green) were merged with images of CD11b (red) as a marker of leucocytes containing neutrophils. Blue represents nuclear staining with DAPI. Arrowheads indicate the localization of NFKB in nuclei of AEC. Scale bars: $20 \mu \mathrm{m}$.

To initiate milk production, mammary glands require activation of STAT5 by prolactin [46]. In normal mammary glands, STAT5 is activated in termination of pregnancy and is rapidly inactivated after weaning, whereas the activation of STAT3 and NFKB is known to be key pathways involved in mammary gland involution [47]. Thus, the inactivation of STAT5 and the activation of STAT3 and NFKB represent the initiation of involution and the end of galactopoiesis. Interestingly, the inactivation of STAT5 and activation of NFKB and STAT3 in AEC also promotes milk loss in the mammary glands after infection $[35,48]$. Both STAT3 and NFKB have been shown to regulate the expression of genes involved in inflammation within the mammary glands in mastitis [49]. These reports have clearly shown the importance of STAT3, STAT5 and NFkB for shutdown of galactopoiesis in mastitis. However, it remains unclear how early the shutdown of galactopoiesis occurs in mastitis. Our study shows that the inactivation of STAT5 and activation of STAT3 and NFKB occurred at $3 \mathrm{~h}$ after LPS injection with down-regulation of genes relevant to the milk component production process and up-regulation of lactoferrin. AEC bind to LPS via Toll-like receptor 4 , and the binding of LPS to Toll-like receptor 4 stimulates the activation of $\mathrm{NF} K \mathrm{~B}$, recognized as translocation of $\mathrm{NF} \kappa \mathrm{B}$ from the cytoplasm to the nucleus [31]. Therefore, it is suggested that the rapid shutdown of galactopoiesis is induced through the binding of LPS to AEC and the activation of STAT3 and NFkB immediately after infection in mastitis. The recruitment of CD11b-positive leukocytes into the alveolar lumen, which is one of the symptoms in early mastitis, may occur after the shutdown of milk component production in AEC $[1,41]$.

In this study, the down-regulation of lactation-specific genes relevant to nutrient uptake and synthesis of milk components occurred between 3 and $6 \mathrm{~h}$ after LPS injection. Immunostaining images of $\beta$-casein and adipophilin in AEC also revealed the posttranslational influences of LPS on the milk secretion process within $6 \mathrm{~h}$ after LPS injection. On the contrary, the amount of accumulated milk components (triglycerides, lactose, $\beta$-casein) in the alveolar lumens and ducts did not decrease until $12 \mathrm{~h}$ after LPS injection. These results suggest that LPS causes the abnormal accumulation of milk components in the alveolar lumens and ducts. We previously reported that myoepithelial cells maintain a contracted state at least for $12 \mathrm{~h}$ after LPS treatment [36]. The contraction of the smooth muscle in myoepithelial cells by oxytocin stimuli is required for milk ejection from the alveolar lumen [50]. The mice lacking smooth muscle actin are also unable to nurse their offspring [50,51]. LPS treatment may cause a defective milk ejection from alveolar lumen by myoepithelial cells in addition to the shutdown of galactopoiesis.

In summary, our results show that the expression of genes relevant to the three-staged milk component production process, consisting of nutrient uptake, synthesis, and secretion of milk components in AEC, are rapidly down-regulated in association with the inactivation of STAT5 and the activation of STAT3 and NFkB. Some of the proteins relevant to the milk component production process also show abnormal localization after LPS 
injection. Therefore, we suggest that lactating mammary glands rapidly shut down the milk production process after LPS injection through expressional control and posttranslational changes of proteins contributing to milk component production in AEC. However, several additional proteins and signaling pathways, which were not investigated in this study, have been reported to contribute to specific milk component production processes in AEC. Furthermore, AEC are surrounded by myoepithelial cells, microvascular endothelial cells, adipocytes, and several immune cell types such as macrophages and neutrophils. We previously reported that the cell-specific behavior and the tissue remodeling of the alveolus occur after LPS injection in accordance with disruption of the milk-blood barrier [36,37]. It is also suggested that the milk component production process is more intricately regulated.

\section{Competing interests}

The authors declare that they have no competing interests.

\section{Authors' contributions}

KK: designed the study; analysis and interpretation of data; drafted the manuscript. SO, CK and TU: carried out the immunostaining studies and cell culture. RMM: interpreted data; revised the manuscript. HK: interpreted data; helped draft the manuscript; revised the manuscript. All authors read and approved the final manuscript.

\section{Acknowledgements}

This work was supported by a Grant-in-Aid for Young Scientists (24780281) from the Japan Society of Promotion of Science, a Grant-in-Aid for Specially Promoted Research from the Ministry of Education, Culture, Sports, Science, and Technology

Received: 12 August 2013 Accepted: 19 November 2013 Published: 5 December 2013

\section{References}

1. Akers RM, Nickerson SC: Mastitis and its impact on structure and function in the ruminant mammary gland. J Mammary Gland Biol Neoplasia 2011, 16:275-289.

2. Djonov $\mathrm{V}$, Andres $\mathrm{AC}$, Ziemiecki $\mathrm{A}$ : Vascular remodelling during the normal and malignant life cycle of the mammary gland. Microsc Res Tech 2001, 52:182-189.

3. Matsuzaki T, Machida N, Tajika Y, Ablimit A, Suzuki T, Aoki T, Hagiwara H, Takata K: Expression and immunolocalization of water-channel aquaporins in the rat and mouse mammary gland. Histochem Cell Biol 2005, 123:501-512.

4. Camps M, Vilaro S, Testar X, Palacin M, Zorzano A: High and polarized expression of GLUT1 glucose transporters in epithelial cells from mammary gland: acute down-regulation of GLUT1 carriers by weaning. Endocrinology 1994, 134:924-934.

5. Stahl A: A current review of fatty acid transport proteins (SLC27). Pflugers Arch 2004, 447:722-727.

6. Han LQ, Li HJ, Wang YY, Zhu HS, Wang LF, Guo YJ, Lu WF, Wang YL, Yang GY: mRNA abundance and expression of SLC27A, ACC, SCD, FADS LPIN, INSIG, and PPARGC1 gene isoforms in mouse mammary glands during the lactation cycle. Genet Mol Res 2010, 9:1250-1257.

7. Laspiur JP, Burton JL, Weber PS, Kirkwood RN, Trottier NL: Short communication: amino acid transporters in porcine mammary gland during lactation. J Dairy Sci 2004, 87:3235-3237.

8. Wartmann M, Cella N, Hofer P, Groner B, Liu X, Hennighausen L, Hynes NE: Lactogenic hormone activation of Stat5 and transcription of the betacasein gene in mammary epithelial cells is independent of p42 ERK2 mitogen-activated protein kinase activity. J Biol Chem 1996, 271:31863-31868.
9. Buser AC, Obr AE, Kabotyanski EB, Grimm SL, Rosen JM, Edwards DP. Progesterone receptor directly inhibits beta-casein gene transcription in mammary epithelial cells through promoting promoter and enhancer repressive chromatin modifications. Mol Endocrinol 2011, 25:955-968.

10. Gallego MI, Binart N, Robinson GW, Okagaki R, Coschigano KT, Perry J, Kopchick JJ, Oka T, Kelly PA, Hennighausen L: Prolactin, growth hormone, and epidermal growth factor activate Stat5 in different compartments of mammary tissue and exert different and overlapping developmental effects. Dev Biol 2001, 229:163-175.

11. Neville MC, MCFadden TB, Forsyth I: Hormonal regulation of mammary differentiation and milk secretion. J Mammary Gland Biol Neoplasia 2002, 7:49-66.

12. Shaper NL, Charron M, Lo NW, Shaper JH: Beta1,4-galactosyltransferase and lactose biosynthesis: recruitment of a housekeeping gene from the nonmammalian vertebrate gene pool for a mammary gland specific function. J Mammary Gland Biol Neoplasia 1998, 3:315-324.

13. Brew K, Vanaman TC, Hill RL: The role of alpha-lactalbumin and the A protein in lactose synthetase: a unique mechanism for the control of a biological reaction. Proc Natl Acad Sci USA 1968, 59:491-497.

14. Stein O, Stein Y: Lipid synthesis, intracellular transport, and secretion. II. Electron microscopic radioautographic study of the mouse lactating mammary gland. J Cell Biol 1967, 34:251-263.

15. Anderson SM, Rudolph MC, McManaman JL, Neville MC: Key stages in mammary gland development. Secretory activation in the mammary gland: it's not just about milk protein synthesis! Breast Cancer Res 2007, 9:204.

16. Rudolph MC, Monks J, Burns V, Phistry M, Marians R, Foote MR, Bauman DE, Anderson SM, Neville MC: Sterol regulatory element binding protein and dietary lipid regulation of fatty acid synthesis in the mammary epithelium. Am J Physiol Endocrinol Metab 2010, 299:E918-E927.

17. Rudolph MC, Neville MC, Anderson SM: Lipid synthesis in lactation: diet and the fatty acid switch. J Mammary Gland Biol Neoplasia 2007, 12:269-281.

18. McManaman JL, Reyland ME, Thrower EC: Secretion and fluid transport mechanisms in the mammary gland: comparisons with the exocrine pancreas and the salivary gland. J Mammary Gland Biol Neoplasia 2006, 11:249-268.

19. Sollner $T$, Whiteheart SW, Brunner M, Erdjument-Bromage $H$, Geromanos $S$ Tempst $P$, Rothman JE: SNAP receptors implicated in vesicle targeting and fusion. Nature 1993, 362:318-324.

20. Jahn R, Scheller RH: SNAREs-engines for membrane fusion. Nat Rev Mol Cell Biol 2006, 7:631-643.

21. McNew JA, Parlati F, Fukuda R, Johnston RJ, Paz K, Paumet F, Sollner TH, Rothman JE: Compartmental specificity of cellular membrane fusion encoded in SNARE proteins. Nature 2000, 407:153-159.

22. Scales SJ, Chen YA, Yoo BY, Patel SM, Doung YC, Scheller RH: SNAREs contribute to the specificity of membrane fusion. Neuron 2000, 26:457-464.

23. Chat S, Layani S, Mahaut C, Henry C, Chanat E, Truchet S: Characterisation of the potential SNARE proteins relevant to milk product release by mouse mammary epithelial cells. Eur J Cell Biol 2011, 90:401-413.

24. Mather IH, Keenan TW: Origin and secretion of milk lipids. J Mammary Gland Biol Neoplasia 1998, 3:259-273.

25. Olofsson SO, Bostrom P, Andersson L, Rutberg M, Perman J, Boren J: Lipid droplets as dynamic organelles connecting storage and efflux of lipids. Biochim Biophys Acta 2009, 1791:448-458.

26. Schwertfeger KL, McManaman $\mathrm{L}$, Palmer CA, Neville MC, Anderson SM: Expression of constitutively activated Akt in the mammary gland leads to excess lipid synthesis during pregnancy and lactation. J Lipid Res 2003, 44:1100-1112.

27. McManaman JL, Russell TD, Schaack J, Orlicky DJ, Robenek H: Molecular determinants of milk lipid secretion. J Mammary Gland Biol Neoplasia 2007, 12:259-268.

28. Chong BM, Reigan P, Mayle-Combs KD, Orlicky DJ, McManaman JL: Determinants of adipophilin function in milk lipid formation and secretion. Trends Endocrinol Metab 2011, 22:211-217.

29. Rudolph MC, McManaman JL, Hunter L, Phang T, Neville MC: Functional development of the mammary gland: use of expression profiling and trajectory clustering to reveal changes in gene expression during pregnancy, lactation, and involution. J Mammary Gland Biol Neoplasia 2003, 8:287-307. 
30. Silanikove N, Rauch-Cohen A, Shapiro F, Blum S, Arieli A, Leitner G: Lipopolysaccharide challenge of the mammary gland in bovine induced a transient glandular shift to anaerobic metabolism. J Dairy Sci 2011, 94:4468-4475.

31. Doyle SL, O'Neill LA: Toll-like receptors: from the discovery of NFkappaB to new insights into transcriptional regulations in innate immunity. Biochem Pharmacol 2006, 72:1102-1113.

32. Schmitz S, Pfaffl MW, Meyer HH, Bruckmaier RM: Short-term changes of mRNA expression of various inflammatory factors and milk proteins in mammary tissue during LPS-induced mastitis. Domest Anim Endocrinol 2004, 26:111-126.

33. Baumert A, Bruckmaier RM, Wellnitz O: Cell population, viability, and some key immunomodulatory molecules in different milk somatic cell samples in dairy cows. J Dairy Res 2009, 76:356-364.

34. Wellnitz O, Arnold ET, Bruckmaier RM: Lipopolysaccharide and lipoteichoic acid induce different immune responses in the bovine mammary gland. J Dairy Sci 2011, 94:5405-5412.

35. Connelly L, Barham W, Pigg R, Saint-Jean L, Sherrill T, Cheng DS, Chodosh LA, Blackwell TS, Yull FE: Activation of nuclear factor kappa B in mammary epithelium promotes milk loss during mammary development and infection. J Cell Physiol 2010, 222:73-81.

36. Kobayashi K, Uejyo T, Oyama S, Rahman MM, Kumura H: Histological analysis of mammary gland remodeling caused by lipopolysaccharide in lactating mice. Cell Tissue Res. in press.

37. Kobayashi K, Oyama S, Numata A, Rahman MM, Kumura H: Lipopolysaccharide disrupts the milk-blood barrier by modulating claudins in mammary alveolar tight junctions. PLoS One 2013, 8:e62187.

38. Mohammad MA, Hadsell DL, Haymond MW: Gene regulation of UDPgalactose synthesis and transport: potential rate-limiting processes in initiation of milk production in humans. Am J Physiol Endocrinol Metab 2012, 303:E365-E376.

39. Brantley DM, Yull FE, Muraoka RS, Hicks DJ, Cook CM, Kerr LD: Dynamic expression and activity of NF-kappaB during post-natal mammary gland morphogenesis. Mech Dev 2000, 97:149-155.

40. Bertucci PY, Quaglino A, Pozzi AG, Kordon EC, Pecci A: Glucocorticoidinduced impairment of mammary gland involution is associated with STAT5 and STAT3 signaling modulation. Endocrinology 2010, 151:5730-5740.

41. Diez-Fraille A, Mehrzad J, Meyer E, Duchateau L, Burvenich C: Comparison of L-selectin and Mac-1 expression on blood and milk neutrophils during experimental Escherichia coli-induced mastitis in cows. Am J Vet Res 2004, 65:1164-1171.

42. Notebaert S, Demon D, Vanden Berghe T, Vandenabeele P, Meyer E: Inflammatory mediators in Escherichia coli-induced mastitis in mice. Comp Immunol Microbiol Infect Dis 2008, 31:551-565.

43. Strandberg Y, Gray C, Vuocolo T, Donaldson L, Broadway M, Tellam R: Lipopolysaccharide and lipoteichoic acid induce different innate immune responses in bovine mammary epithelial cells. Cytokine 2005, 31:72-86.

44. Legrand D, Elass E, Carpentier M, Mazurier J: Lactoferrin: a modulator of immune and inflammatory responses. Cell Mol Life Sci 2005, 62:2549-2559.

45. Laspiur JP, Burton JL, Weber PS, Moore J, Kirkwood RN, Trottier NL: Dietary protein intake and stage of lactation differentially modulate amino acid transporter mRNA abundance in porcine mammary tissue. J Nutr 2009, 139:1677-1684

46. Liu X, Robinson GW, Wagner KU, Garrett L, Wynshaw-Boris A, Hennighausen $\mathrm{L}$ : Stat5a is mandatory for adult mammary gland development and lactogenesis. Genes Dev 1997, 11:179-186.

47. Scribner KC, Wellberg EA, Metz RP, Porter WW: Singleminded-2 s (Sim2s) promotes delayed involution of the mouse mammary gland through suppression of Stat3 and NFkappaB. Mol Endocrinol 2011, 25:635-644.

48. Clarkson RW, Boland MP, Kritikou EA, Lee JM, Freeman TC, Tiffen PG, Watson $\mathrm{CJ}$ : The genes induced by signal transducer and activators of transcription (STAT) 3 and STAT5 in mammary epithelial cells define the roles of these STATs in mammary development. Mol Endocrinol 2006, 20:675-685.
49. Pensa S, Watson CJ, Poli V: Stat3 and the inflammation/acute phase response in involution and breast cancer. J Mammary Gland Biol Neoplasia 2009, 14:121-129.

50. Haaksma CJ, Schwartz RJ, Tomasek JJ: Myoepithelial cell contraction and milk ejection are impaired in mammary glands of mice lacking smooth muscle alpha-actin. Biol Reprod 2011, 85:13-21.

51. Weymouth N, Shi Z, Rockey DC: Smooth muscle alpha actin is specifically required for the maintenance of lactation. Dev Biol 2012, 363:1-14.

doi:10.1186/1297-9716-44-119

Cite this article as: Kobayashi et al.: Underlying mechanisms involved in the decrease of milk secretion during Escherichia coli endotoxin induced mastitis in lactating mice. Veterinary Research 2013 44:119.

\section{Submit your next manuscript to BioMed Central and take full advantage of:}

- Convenient online submission

- Thorough peer review

- No space constraints or color figure charges

- Immediate publication on acceptance

- Inclusion in PubMed, CAS, Scopus and Google Scholar

- Research which is freely available for redistribution

Submit your manuscript at www.biomedcentral.com/submit
C Biomed Central 